\title{
Squamous cell carcinoma of the tongue: clinical and morphological analysis of 57 cases and correlation with prognosis
}

\author{
Carcinoma de células escamosas de língua: análise clínica e morfológica \\ de 57 casos e correlação com o prognóstico
}

Marcelo Gadelha Vasconcelos ${ }^{1}$; Rodrigo Porpino Mafra²; Rodrigo Gadelha Vasconcelos ${ }^{3}$; Ana Miryam Costa de Medeiros; Lélia Maria Guedes Queiroz ${ }^{5}$

\begin{abstract}
Introduction: Oral squamous cell carcinoma (OSCC), which represents more than $90 \%$ of head and neck malignant neoplasms, has a poor prognosis due to its high frequency of lymph node metastasis and local invasion. Previous studies have investigated parameters related to the biological behavior of OSCC and its correlation with disease outcome (DO). Objective: To evaluate clinical and morphological data in cases of tongue squamous cell carcinoma (TSCC), correlating these findings with prognosis. Material and methods: Fifty-seven specimens of TSCC were obtained from patients undergoing surgical excision at a referral hospital in Natal, Brazil. Clinical data, such as tumor-node-metastasis (TNM) stage and D0, were collected from medical records. Hematoxylin and eosin-stained sections were analyzed regarding histological grade of malignancy (HGM), based on the system proposed by Bryne (1998). Results: The majority of patients (38.6\%) were diagnosed as TNM stage III, and 57.9\% developed metastases. Remission of the tumor occurred in $77.2 \%$ of the cases. The parameter "metastasis" exhibited a significant association with DO $(\phi=0)$ and TNM stage $(\phi=0.001)$, thus constituting a good indicator of tumor progression. Correlation of HGM and TNM stage with DO was not evidenced. Nevertheless, statistical analysis showed a significant association between HGM and TNM stage $(\phi=0.006$ ). Conclusion: TNM clinical staging and HGM, evaluated in association, may be useful to estimate the prognosis of TSCC.
\end{abstract}

Key words: squamous cell carcinoma; oral pathology; prognosis.

\section{INTRODUCTION}

Oral squamous cell carcinoma (OSCC) is the most common head and neck cancer, accounting for more than $90 \%$ of all tumors in this region ${ }^{(1)}$. The tongue is the most commonly affected site of the oral cavity and has a poor prognosis, probably because of the high frequency of lymph node metastasis ${ }^{(17,19)}$ and local invasion ${ }^{(1)}$. Despite recent advances in treatment for this malignancy, the overall five-year survival rate of patients is usually below $50 \%{ }^{(17)}$.

OSCCs are treated by primary surgical excision, alone or in combination with radiotherapy or chemotherapy in cases of advanced stages of the disease $e^{(11,15,20)}$. Improved prognostic markers would be clinically useful to determine the biological aggressiveness of these tumors and to enable specific appropriate therapies to be applied to each tumor ${ }^{(17,19)}$. Regional lymph node metastasis is one of the most important prognostic factors of $\operatorname{OSCC}^{(1,11,13,17,19,20)}$ and may reduce the cure rate by $50 \%{ }^{(7)}$, but anatomic site ${ }^{(1,22)}$, histological grading systems of malignancy $\left.{ }^{(1,4,}, 5,9,11-13,17,18\right)$, tumor-node-metastasis (TNM) classification of malignant tumors ${ }^{(1,2,5,10,11,13,17,19,21)}$ and depth of invasion ${ }^{(11,19,20)}$ have also been cited as prognostic indicators.

Patientswith OSCCcandie as a result of diagnostic delays, regional lymph node metastases ${ }^{(19)}$ or locoregional recurrences ${ }^{(20)}$. Analysis of

First submission on 23/04/14; last submission on 16/08/14; accepted for publication on $02 / 09 / 14$; published on 20/10/14

1. Doctorate in Oral Pathology from Universidade Federal do Rio Grande no Norte (UFRN); professor at the Dentistry Department of Universidade Estadual da Paraiba (UEPB).

2. Dental surgeon; master's student of Oral Pathology at UFRN.

3. Doctoral student of Oral Pathology at UFRN; professor at the Dentistry Department of UEPB

4. Doctorate in Oral Pathology from UFRN; professor at the Post-Graduate Program in Oral Pathology of UFRN.

5. Doctorate in Oral Pathology from Universidade de São Paulo (USP); professor at the Post-Graduate Program in Oral Pathology of UFRN. 
the prognostic factors is important for predicting the outcome and achieving a high survival rate in these patients ${ }^{(21)}$. Several reports have examined the usefulness of clinical and pathologic factors related to the prognosis of $\operatorname{OSCC}^{(1,2,5,9,10,17-20,22)}$. Therefore, the objective of this study was to analyze the incidence of clinical and morphological data in a series of cases of tongue squamous cell carcinoma (TSCC), as well as their influence in prognosis.

\section{OBJECTIVE}

The aim of this study was to evaluate and correlate clinical and morphological data on 57 TSCC cases, in a Brazilian population, contributing to the knowledge concerning the prognosis of oral cancer.

\section{MATERIAL AND METHODS}

The study was approved by the Research Ethics Committee of Universidade Federal do Rio Grande do Norte (protocol number: 029/10). Fifty-seven TSCC specimens were obtained from patients undergoing definitive surgical resection, at Hospital Dr. Luiz Antônio, located in Natal, Brazil. Patients who had been followed up clinically for at least five years were preferentially selected to determine the presence or absence of cervical lymph node metastases at the time of diagnosis. Patients who had developed cervical or distant lymph node metastases during treatment or follow-up were excluded. Metastases were demonstrated by imaging exams, such as computed tomography or magnetic resonance. Clinical data, such as age, gender, TNM stage and DO, were obtained from the patients' medical records.
For histological analysis, 5- $\mu \mathrm{m}$ thick sections were cut from paraffin-embedded tumor material and stained with hematoxylineosin. Malignancy at the invasion front was evaluated using the histological grading system proposed by Bryne $(1998)^{(7)}$. For each tumor, degree of keratinization, nuclear pleomorphism, invasion pattern, and inflammatory response were analyzed semiquantitatively and given scores of 1 to 4 . Cases with a total score of 4 to 8 were classified as low-grade malignancy, and cases with a total score higher than 8 were classified as high-grade malignancy ${ }^{(10)}$.

\section{RESULTS}

\section{Profile of the sample}

Most patients with TSCC were males (70.2\%) and aged from 61 to 70 years $(35.1 \%)$. Caucasian patients predominated in the sample $(n=32 ; 56.2 \%)$. The combination of smoking and alcohol consumption was the most frequent habit (42.1\%), followed by smoking alone (31.6\%). TNM stage III was the most frequent (38.6\%), followed by stages I, IV and II. As regards the outcome, tumor remission was observed in $77.2 \%$ of the cases, and 57.9\% developed metastases (Tables $\mathbf{1}$ and $\mathbf{2}$ ).

\section{Statistical analysis of the clinical and morphological aspects}

A statistically significant association was found between metastasis and D0, according to the chi-square $\left(\chi^{2}\right)$ test $(p=$ 0.000 ). Among the 24 cases with no metastasis, $100 \%$ achieved remission of the disease. Among the 33 cases with metastasis, less than $40 \%$ of patients died (Table 2 ).

TABLE 1 - Correlation between metastasis and clinical TNM stage. Significance level according to chi-square test $\left(\chi^{2}\right)$

\begin{tabular}{|c|c|c|c|c|c|c|c|c|}
\hline & & \multicolumn{4}{|c|}{ Clinical TNM stage } & \multirow[b]{2}{*}{ Total } & \multirow[b]{2}{*}{$(\chi 2)$} & \multirow[b]{2}{*}{$p$} \\
\hline & & I & II & III & IV & & & \\
\hline \multirow{2}{*}{ Metastasis } & Absent & $8(57.1 \%)$ & $9(90) \%$ & $6(27.3 \%)$ & $1(9.1 \%)$ & $24(100 \%)$ & 17.613 & 0.001 \\
\hline & Total & $14(24.5 \%)$ & $10(17.5 \%)$ & $22(38.6) \%$ & $11(19.3 \%)$ & $57(100 \%)$ & & \\
\hline
\end{tabular}

TNM: tumor-node-metastasis.

TABLE 2 - Correlation between metastasis and disease outcome. Significance level according to chi-square test $(\chi 2)$

\begin{tabular}{|c|c|c|c|c|c|c|}
\hline & & \multicolumn{2}{|c|}{ Disease outcome } & \multirow[b]{2}{*}{ Total } & \multirow[b]{2}{*}{$(\chi 2)$} & \multirow[b]{2}{*}{$p$} \\
\hline & & Remission & Death & & & \\
\hline \multirow{3}{*}{ Metastasis } & Absent & $24(100 \%)$ & $0(0) \%$ & $24(100 \%)$ & 12.248 & 0.000 \\
\hline & Present & $20(60.6 \%)$ & $13(39.4 \%)$ & $33(100 \%)$ & & \\
\hline & Total & $44(77.2 \%)$ & $13(22.8 \%)$ & $57(100 \%)$ & & \\
\hline
\end{tabular}


Considering the relationship between metastasis and clinical TNM stage, there was a greater probability of developing metastasis in more advanced stages (III and IV). In the group with absence of metastasis, most of the sample was at stage II, followed by stage I. The $\chi^{2}$ test showed a statistically significant correlation between the studied variables $(p=0.001)$ (Table 1 ).

Analysis of the relationship between histological grade of malignancy (HGM) and clinical TNM stage showed a greater frequency of low-grade malignancy cases in stages I and II, followed by stages III and IV. In relation to the high-grade cases, a higher prevalence of stages III and IV was found, in comparison to stages I and II. The $\chi^{2}$ test showed statistically significant differences among these variables $(\phi=0.006)$ (Table 3 ).
$100 \%$ and $85.7 \%$ of cases that were in stages I and II, respectively, as well as the predominance of deaths in cases classified in stage IV. In a retrospective study of 130 OSCC cases, patients in stages III and IV had greater death rates, thus showing a statistically significant correlation between TNM stage and $\mathrm{DO}^{(2)}$. Furthermore, in a recent study of 202 TSCC cases, a statistically significant correlation of TNM stage with overall survival and disease-specific survival was reported, emphasizing the relevance of TNM stage as an indicator of prognosis and parameter for treatment decision ${ }^{(17)}$.

Considering the relationship between metastasis and TNM stage, according to the $\chi^{2}$ test, a statistically significant association among these variables $(p=0.001)$ was evidenced, since TSCC lesions in the most advanced stages (III and IV) were more likely to

TABLE 3 - Correlation between histological grade and clinical TNM stage. Significance level according to chi-square test $(\chi 2)$

\begin{tabular}{|c|c|c|c|c|c|c|c|c|}
\hline & & \multicolumn{4}{|c|}{ Clinical TNM stage } & \multirow[b]{2}{*}{ Total } & \multirow[b]{2}{*}{$(\chi 2)$} & \multirow[b]{2}{*}{$p$} \\
\hline & & I & II & III & IV & & & \\
\hline \multirow{3}{*}{ Histologic grade of malignancy } & Low & $8(57.1 \%)$ & $3(21.4) \%$ & $2(14.3 \%)$ & $1(7.1 \%)$ & $14(100 \%)$ & 12.443 & 0.006 \\
\hline & High & $6(14 \%)$ & $7(16.3 \%)$ & $20(46.5 \%)$ & $10(23.3 \%)$ & $43(100 \%)$ & & \\
\hline & Total & $14(24.6 \%)$ & $10(17.5 \%)$ & $22(38.6 \%)$ & $11(19.3 \%)$ & $57(100 \%)$ & & \\
\hline
\end{tabular}

TNM: tumor-node-metastasis

\section{DISCUSSION}

Some studies point to factors which may influence prognosis and survival of OSCC patients, namely: size and location of the primary tumor, regional lymph node involvement, presence of distant metastasis, and $\mathrm{HGM}^{(20)}$. In a retrospective study, Goldstein et $a l^{(11)}$ evaluated the association of other clinicopathologic parameters with the outcome of TSCC. They found a statistically significant correlation between the occurrence of relapses and the variables "tumor size", "invasion depth", "surgical margin involvement" and "HGM".

The TNM staging system has been the main indicator of prognosis in OSCC patients ${ }^{(13)}$. This system consists of an anatomical staging, proposed by the International Union Against Cancer, which describes the local extent of the primary tumor, as well as the involvement of regional lymph nodes and of distant sites. Following quantification of those prognostic parameters, tumors are classified in stages ranging from I to IV, and it is well established in literature that the head and neck SCCs classified as stage I exhibit better prognoses than those in stage $\mathrm{IV}^{(1,2,15)}$.

In view of these considerations, although TNM classification is considered a factor associated to prognosis ${ }^{(5,10)}$, in our study we could not demonstrate a statistically significant relationship between TNM stage and DO. However, we verified remission of the lesion in develop metastases (Table 1). We also found a significant correlation between metastasis and D0, considering that the 24 cases (100\%) with absence of metastasis achieved remission of the disease, although among the 33 cases with metastasis, $39.4 \%$ of the patients died (Table 2). Thus, metastasis constitutes a good indicator of tumor progression, directly influencing regional disease control and survival rate, as highlighted in previous studies ${ }^{(4,6)}$.

While several clinical parameters are related to the aggressiveness of OSCC, many aspects regarding the progression and biological behavior of this neoplasm are still unclear, particularly morphological characteristics, considered a controversial issue in the literature ${ }^{(5,9,18)}$. Currently, there are several HGM systems for OSCC described in the literature, as already mentioned, with the purpose of providing morphological subsidies for an interpretation of tumor aggressiveness ${ }^{(13)}$.

In spite of attempts to improve the accuracy of HGM methods, by using scores based on mathematical data, the analysis of morphological parameters is based on the subjectivity of findings, what may lead to conflicting results. Considering these facts, the use of histological grading systems represents additional information for determining the prognosis of $\operatorname{OSCC}^{(1,4)}$.

Among all HGM methods, we can emphasize the system recommended by Bryne in 1998 $8^{(7)}$ : because the key molecular events related to tumor dissemination (changes of adhesion 
molecules, secretion of proteolytic enzymes, increased cell proliferation and initiation of angiogenesis) occur in tumor-host interface (invasion front), the author proposes a grading system which restricts morphological evaluation to the invasion front. This method represents an adaptation of a system proposed by Bryne et al. in $1989^{(8)}$. In this new grading, the criterion "number of mitoses" was removed, while the parameters "degree of keratinization", "cellular pleomorphism", "invasion pattern" and "intensity of the inflammatory infiltrate" remained.

Bryne ${ }^{(7)}$ and Noguchi et al. ${ }^{(16)}$ reported that cells from the invasion front are less differentiated and present a high degree of cell dissociation in comparison to other areas of the tumor. In view of this, one can infer that the invasion front constitutes one of the resources for comprehension of the tumor biological behavior, providing additional information on the choice of therapeutic strategies for OSCC patients, whereas the tool for better understanding of the invasive and metastatic behavior of neoplastic cells consists of the analysis of tumor margins.

In the present study, the HGM system recommended by Bryne ${ }^{(7)}$ was adopted, considering that it is a quick and easily performed method that presents prognostic value, what was demonstrated in previous researches ${ }^{(1,3,4,7)}$. Similarly to these investigations, we opted to use the modification proposed by Miranda ${ }^{(14)}$, in order to classify the SCC lesions according to the degree of malignancy.

The majority of cases were defined as high grade (75.4\%), with no significant association with the variables "DO" and "metastasis". However, it was descriptively demonstrated that most low- and high-grade cases correlated with disease remission and metastasis, respectively. Our results partially support the findings of previous studies, which demonstrated lack of correlation between HGM and prognostic variables, such as overall survival ${ }^{(1,13,18)}$.

In contrast, regarding the analysis of the relation between HGM and clinical TNM staging, a greater frequency of low- and highmalignancy cases was evidenced statistically $(\phi=0.006)$ in early (I and II) and advanced stages (III and IV), respectively (Table 3). These considerations are in agreement with previous studies ${ }^{(0,12)}$, which reported that histological grading at the invasion front has prognostic value for OSCC, although other TNM system-related parameters may present more statistically significant results. Therefore, in the current study, metastasis constituted an indicator of biological behavior in cases of TSCC, since this variable was directly related to DO (death/remission) and clinical TNM stage, whereas HGM showed a significant correlation only with clinical stage.

\section{CONCLUSION}

Based on our results regarding clinical and morphological parameters, we believe that the TNM system and HGM, associated, may be useful tools for predicting high recurrence rate, poor survival rate and disease-free time of TSCC, thus contributing significantly to the understanding of the biological behavior of this neoplasm.

\section{RESUMO}

Introdução: O carcinoma de células escamosas oral (CCEO) representa mais de 90\% das neoplasias malignas de cabeça epescoço. Possui prognóstico desfavorável devido à alta frequência de metástase linfonodal e invasão local. Estudos anteriores investigaram parâmetros relacionados com o comportamento biológico do CCEO e sua correlação com o desfecho clínico. Objetivo: Avaliar dados clínicos e morfológicos em casos de carcinoma de células escamosas de língua (CCEL), correlacionando esses achados com o prognóstico. Material e métodos: Cinquenta e sete espécimes de CCEL foram obtidos de pacientes submetidos à excisão cirúrgica em um hospital de referência de Natal, Brasil. Dados clínicos, a exemplo do estágio tumor-linfonodo-metástase (TNM) e do desfecho da doença (DD), foram coletados dos prontuários médicos. Secções histológicas coradas em hematoxilina e eosina foram analisadas quanto à gradação bistológica de malignidade (GHM), com base no sistema de Bryne (1998). Resultados: A maioria dos pacientes (38,6\%) foi diagnosticada no estágio TNM III, e 57,9\% desenvolveram metástases. A remissão do tumor ocorreu em $77,2 \%$ dos casos. O parâmetro metástase apresentou associação significativa com o DD $(\mathrm{p}=0)$ e o estágio TNM $(\mathrm{p}=$ 0,001), constituindo, dessa forma, um bom indicador de progressão da neoplasia. Não se observou correlação de GHM e estágio TNM com DD, contudo a análise estatística revelou associação significativa entre GHM e estágio TNM ( $\mathrm{p}=0,006)$. Conclusão: 0 estadiamento clínico TNM e a GHM, avaliados em conjunto, podem ser úteis para determinar o prognóstico do CCEL.

Unitermos: carcinoma de células escamosas; patologia bucal; prognóstico. 


\section{REFERENCES}

1. ALVES, P. M. et al. Significance of galectins-1, -3, -4 and -7 in the progression of squamous cell carcinoma of the tongue. Pathol Res Pract, v. 207 , n. 4, p. 236-40, 2011

2. ARAÚJO JÚNIOR, R. F., COSTA, A. L. L., RAMOS, C. F. Parâmetros clínicopatológicos como indicadores de prognóstico em carcinoma epidermoide oral. Pesq Bras Odontoped Clin Integr João Pessoa, v. 6, n. 2, p. 125-30, 2006.

3. BÀNKFALVI, A.; PIFFKÒ, J. Prognostic and predictive factors in oral cancer: the role of the invasive tumour front. J Oral Pathol Med, v. 29, n. 7, p. 291-8, 2000

4. BARROS, S. S. L. V. Expressão imuno-bistoquímica de metaloproteinases em carcinoma epidermóide de lábio inferior e lingua. Natal, 2006. Tese (Doutorado em Patologia Oral) - Universidade Federal do Rio Grande do Norte.

5. BELL, R. B. et al. Tongue cancer: is there a difference in survival compared with other subsites in the oral cavity? J Oral Maxillofac Surg, v. 65 , n. 2, p. 229-36, 2007.

6. BETTENDORF, 0.; PIFFKÒ, J.; BÀNKFALVI, A. Prognostic and predictive factors in oral squamous cell cancer: important tools for planning individual therapy? Oral Oncol, v. 40, n. 2, p. 110-9, 2004.

7. BRYNE, M. Is the invasive front of an oral carcinoma the most important area for prognostication? Oral Dis, v. 4, n. 2, p. 70-7, 1998

8. BRYNE, M. et al. New malignancy grading is a better prognostic indicator than Broders' grading in oral squamous cell carcinomas. J Oral Pathol Med, v. 18, n. 8, p. 432-7, 1989.

9. COSTA, A. L. L.; ARAÚJO JÚNIOR, R. F; RAMOS, C. C. F. Correlation between TNM classification and malignancy histological feature of oral squamous cell carcinoma. Rev Bras Otorrinolaringol, v. 71, n. 2, p. 181$7,2005$.

10. GARAVELLO, W. et al. Prognostic influence of gender in patients with oral tongue cancer. Otolaryngol Head Neck Surg, v. 138, n. 6, p. 768-71, 2008.
11. GOLDSTEIN, D. P. et al. Outcomes of squamous cell cancer of the oral tongue managed at the Princess Margaret Hospital. Head Neck, v. 35, n. 5 , p. $632-41,2013$

12. KUROKAWA, H. et al. The high prognostic value of the histologic grade at the deep invasive front of tongue squamous cell carcinoma. J Oral Pathol Med, v. 34, n. 6, p. 329-33, 2005.

13. LINDENBLATT, R. C. R. et al. Oral squamous cell carcinoma grading systems - analysis of the best survival predictor.J Oral Pathol Med, v. 41, n. 1, p. 34-9, 2012.

14. MIRANDA, J. L. Expressão de proteinas da matriz extracelular em carcinoma epidermóide de língua e lábio inferior. Natal, 2002. Tese (Doutorado em Patologia Oral) - Universidade Federal do Rio Grande do Norte.

15. NEVILLE, B. W. et al. Patologia oral \& maxilofacial. 3. ed. Rio de Janeiro: Elsevier, 2009.

16. NOGUCHI, M. et al. Invasive front in oral squamous cell carcinoma: image and flow cytometric analysis with clinicopathologic correlation. Oral Surg Oral Med Oral Pathol Oral Radiol Endod, v. 93, n. 6, p. 682-7, 2002.

17. RODRIGUES, P. C. et al. Clinicopathological prognostic factors of oral tongue squamous cell carcinoma: a retrospective study of 202 cases. Int J Oral Maxillofac Surg, v. 43, n. 7, p. 795-801, 2014.

18. SILVEIRA, E. J. D. et al. Correlation of clinical, histological and cytokeratin profiles of squamous cell carcinoma of the tongue with prognosis. Int J Surg Pathol, v. 15, n. 4, p. 376-83, 2007.

19. SÜSLÜ, N. et al. Carcinoma of the oral tongue: a case series analysis of prognostic factors and surgical outcomes.J Oral Maxillofac Surg, v. 71, n. 7, p. 1283-90, 2013.

20. THIAGARAJAN, S. et al. Predictors of prognosis for squamous cell carcinoma of oral tongue.J Surg Oncol, v. 109, n. 7, p. 639-44, 2014.

21. WANG, X. et al. Intratumor genomic heterogeneity correlates with histological grade of advanced oral squamous cell carcinoma. Oral Oncol, v. 42, n. 7, p. 740-4, 2006.

22. WANG, Y. et al. Reasons for recurrence and prognostic analysis of early stage squamous cell carcinoma of the oral tongue. Ai Zheng, v. 28, n. 5, p. 524-7, 2009

\section{MAILING ADDRESS}

Lélia Maria Guedes Queiroz

Departamento de Odontologia; Programa de Pós-Graduação em Patologia Oral; Av. Senador Salgado Filho, 1.787; Lagoa Nova; CEP: 59056-000; Natal-RN, Brazil; e-mail: lmgqueiroz@hotmail.com. 